\title{
THE RELATION BETWEEN STATE AND PRIVATE FORESTRY ${ }^{1}$
}

\author{
BY. F. D. Mulholland \\ Canadian Western Lumber Co. Ltd., Vancouver, B.C.
}

$\mathrm{T}$

HIS subject is by no means new to our Society. However, I think the Programme Committee is justified in giving it a prominent place at this meeting because of the importance attached to it by industry and the profession, as evidenced before the Sloan Commission and elsewhere. It is justified also in providing an opportunity to clarify our own opinions in the matter.

In any discussion the establishment of two definite and opposing points of view helps to dissipate a fog of irrelevancies. With that object I shall take the liberty of stating two extremes as a provocative sub-title; "Shall Forestry in Canada be free or a State Monopoly?":

It is an old problem. Eight hundred and fifty years ago the King of England, finding himself with a quite inadequate area of forest, increased his holdings by arbitrary seizure and depopulation of lands, and maintained them by some of the most savage laws in history. Through centuries the Royal Forester was not only a silvicultural and game expert but also a policeman, prosecutor and judge of forest offences.

The subject of the State's function in forestry was introduced at last year's Regina meeting after some ingenious verbal manipulation of programme titles by the Chief Forester of the B.C. Forest Service. My own opinions were expressed in an address to members of this Society seven years ago. Both addresses were printed in the "Forestry Chronicle". As you all have good memories I fear my remarks today will lack the interest of novelty.

Before going further I want to preclude misunderstandings which might be caused by differences in definition of terms. What is the nature of this "State" whose relation to forestry we are discussing, and what is State Forestry?

After being given this assignment I asked a few friends what meaning they gave to the term "State". An easy question. Canada, of course; or, on second thoughts, British Columbia, because natural resources are a Provincial responsibility. State forests, therefore, are Provincial Government lands.

It is not uncommon for people to confuse State and Government. It is a dangerous practice. Opposition to the State is treason, but when opposition to the Government ceases we shall no longer be a democracy. Free men will not support the apotheosis of Government, and they realize that human happiness depends upon maintaining the importance and the dignity, the initiative and the rights of the individual rather than upon the transcendence of the State.

\footnotetext{
1 Paper presented at the 39th annual meeting of the Canadian Society of Forest Engineers, Vancouver, B.C., February 26-28, 1947.
} 
You should not think that these remarks are irrelevant, because surely we must make up our minds about the State and Government before we can reasonably decide what the State's relation to forestry or any other industry or occupation should be.

The State's duty is to protect the life, health and property of its citizens. I do not believe it should seek to own any more land than is needed to carry out this function. I believe it to be the Government's duty in a new country such as Canada to make the natural resources available for their proper use by private individuals and not to hold them for it's own profit. It is certainly the Government's right and duty to see that the private individual does not use or misuse his property to the detriment of his fellow citizens, but for the Government to refuse to allow private citizens to acquire land for proper use, is to admit that it has a low opinion of its people and mistrusts its own power to control abuses. If the control exercised by the force of public opinion and custom is not adequate surely it can be achieved by education or, if necessary, by law and regulation.

Hitherto it has not been considered the Government's function in democracies to go into business; whether manufacturing, farming or growing trees, except in a national emergency, and after the failure of private enterprise. In a word, I believe that the more land the Government can sell or lease to private individuals to grow trees upon, the better for the State.

Reduced to its simplest terms forestry is, after all, the business of growing trees; it is a form of agriculture. It is the use of a natural resource for human sustenance and enjoyment. In a democracy of reasonable intelligence it is not really necessary that this occupation be reserved for men hired by the Government, nor even for tenants of the Crown. Independent citizens can undertake it quite satisfactorily, just as they use the natural resources for farming, mining, and building homes and gardens. Forests are grown that way in the older countries where forestry is far more advanced than it is in Canada.

What is the present ownership of forest land? According to Federal statistics quoted in the "Chronicle", Canada has 781 million acres of forest land, of which only 8 per cent is privately owned. This, however, includes what we classify here as non-commercial forest or scrub land. The forests capable of producing commercial timber, by our present standards, cover 490 million acres, of which 13 per cent are privately owned and 22 per cent leased. Of the forests at present considered accessible about 24 per cent are privately owned, 40 per cent leased, and 36 per cent unalienated Crown lands.

As responsibility for the natural resources in our country lies upon the Province, it is more practical to deal with the function of the State in a Province.

Using Forest Service statistics, of British Columbia's 75 million acres of commercially valuable forest 93 per cent are Crown land, that is, State owned or controlled. Only 7 per cent of the forest land is privately owned, with another 4 per cent held under various form of lease or licence for logging. 
It is sometimes said that this condition indicates that our Governments have followed almost from the beginning a wise policy of State ownership in order to conserve the forests for perpetual production. I have no criticism of the distinguished gentlemen who have expressed this opinion; a few years ago I almost believed it myself. But a more careful study of the actions of the Legislature in disposing of land in the earlier days of the Province does not support this view.

There was probably no thought of permanent forestry in the minds of early legislators; it is unlikely that they would think of growing a second crop in the presence of apparently inexhaustible forests of mature timber. It is more likely that the early difficulties experienced in establishing a market caused little demand for timber. In point of fact early Governments did all they could to raise revenue from the forests by sale, lease or licence; any method of disposal which might bring money to the Treasury. Let me quote from the argument of Mr. D. N. Hossie, K.C., before the Royal Commission on Forestry in 1945. In passing I would like to commend to the members of this Society Mr. Hossie's account of the course of alienation of Crown forest lands since the formation of the Province in 1858, and also his account of other matters. I wish his whole argument, 70 typewritten pages, could be printed and distributed to all foresters; they would find it very instructive.

Quoting Mr. Hossie: "The Legislature of this Province set out to get a revenue from this timber land as far back as 1858 and they charged all the traffic would bear. They sold the land and made it clear that the trees went with the land. They offered it at 10 shillings and there were not enough takers, so they reduced the price to $4 \mathrm{~s}$. $2 \mathrm{~d}$, which is the equivalent of one dollar. It was not until 17 years of such sales had proved insufficient that the Government offered timber leases; and then in 1884 they offered timber licences as well."

In 1884 the price was raised to $\$ 2.50$ per acre, still with no royalty. In 1887 the first royalty was reserved on Crown grants, $25 \mathrm{c}$. per thousand feet next year the royalty was 50c.- probably the Government could not get a higher price for the timber, cash down, so they got it through this deferred payment method.

After 1884 settlers could still buy timber land for $\$ 1.00$ per acre by pre-emption. This privilege was undoubtedly abused, and in 1896 the sale of timber land, containing an average of over $8,000 \mathrm{f.b} . \mathrm{m}$. per acre on the Coast or 5,000 f.b.m. in the Interior, was prohibited. This enabled the Crown to get a greater revenue for its timber from the royalty or deferred payment on leases and licences. Neither the Crown nor the purchasers troubled themselves with the thought of reforestation after logging. It is true that some 40 years ago a Minister said a new type of licence would safeguard posterity's interest in the forest for all time. Posterity's interest has not yet suffered any remarkable damage, but not because of his licences. His justification was that he had made the amount of consideration to be paid for the timber a royalty which could be raised from time to time as circum. 
stances might warrant. The licences greatly enriched the Treasury and thousands of them reverted to the Crown before any timber was removed so that the Government was in the happy position of being able to sell it twice.

It was not until after the report of the Royal Commission appointed in 1910, which resulted in the formation of the Forest Service in 1912, that real provision was made for permanent forestry. The Act of 1912 provided for the establishment of Crown forest reserves for the perpetual production of timber or the protection of watersheds. Some reserves were made in 1922 to protect the Okanagan watersheds and an active programme of survey and creation of productive reserves began in 1925. However, even to this day they are not being managed on a sustained yield plan.

With Crown ownership predominating so greatly it was hardly to be expected that the private owners would be interested in permanent forestry earlier than the Government. It would, in fact, have been very uneconomical and foolish to spend money on reforestation and silviculture while mature virgin timber covered 90 per cent of the forest land (it still covers 70 per cent) on the Coast, and was for sale at reasonable prices.

Of course, forestry can be developed only as fast as the country's economic situation will permit. In British Columbia there is still enough virgin timber for half a century at our present rate of logging and, therefore, little value has been attached to a second crop. Mistaken systems of taxation have speeded the return of cut-over lands to the Crown domain. Consequently, the Government Forest Service has been compelled to protect and manage, to the best of its ability, far too great a proportion of the land surface of the Province. Unless the tide can be turned and private enterprise persuaded to acquire and properly manage much more forest land, the future of the industry will not be bright.

These events of the past and hopes for the future have made State forestry here a very composite matter. Examination of the relevant legislation discloses that it includes ownership and management of productive forests, parks, grazing and wild lands; prevention of trespass; inspection of private forest operations; examination and classification of lands. It requires business and technical executives, surveyors, cruisers, assessors, tax-gatherers, rent collectors, policemen, engineers and mechanics. It has a sales organization and a fire brigade. It is an inspection and law enforcement agency. It employs experts and research scientists in silviculture agronomy and other sciences. It is very expansive-it must be so long as Government allots these multifarious duties to it.

State forest responsibility seems to fall under four main heads:-

(1) Protection of all forest land:

(2) Management of Crown forest:

(3) General supervision of and collection of revenue from private forests:

(4) Research, statistical and scientific studies, and public education. 
With regard to the first the Sloan Commission reported that "Fire protection in relation to both personnel and equipment is grossly inadequate." Since then the Government has largely increased its appropriation for this purpose. However, the allocation of the funds provided is of equal importance. Private operators fight most of their fires themselves; and what is chiefly needed from the Government is adequate provision for detection and communication-look-outs, air patrol, radio and telephone, meteorological stations, and warning systems. Also, better control of the public hazard is required, especially in logged and re-forested areas. Protection from insects and disease is almost entirely confined to research and study of epidemics by the Dominion Government departments. This work needs to be expanded; and more funds should be made available for the control of epidemics by the Province.

The Government's interest in private forestry hitherto has been almost exclusively concerned with prevention of fire hazards and collection of revenue. The Sloan Commission drew attention to the necessity for relief from taxation based on a liquidation policy. It is encouraging to hear that the Government has now before the Legislature a Bill to provide for the estab. lishment of management units of Crown lands for sustained yield forestry. It can be improved by removal of some arbitrary clauses, and with some ironing out by experience it is probable that it will be of great assistance to that part of the industry which draws its supplies from Crown lands.

It is to be hoped that before another year goes by the Government will be prepared to implement the Sloan report further and relieve the taxation burden on logged and reforested private lands, so as to enable their owners to grow successive forest crops with a reasonable hope of keeping their accounts on the right side of the ledger. I refer not only to large land owners, and that means companies with thousands of shareholders who have risked their money on the venture, but also to farmers and other owners of a few hundred acres of Crown-granted forest land. This class of owner in some countries where forestry is well administered accounts for a very large proportion of the annual production of wood. Here it would also seem that the Government is opposed to the practice of forestry on such areas. For example; if the owner of land which has been bought and paid for, and upon which he pays annual land and school taxes, decides to grow and sell even Christmas trees, or pea sticks, because the land is not arable, he will be presented with a bill for royalty. He can grow ornamental trees for city gardens, and escape this double taxation. The logic of this situation does not appear to be sound.

If you buy a farm at harvest time, with a crop standing upon it, you expect to pay for the crop in addition to the land, and that payment in the case of timber is called Royalty; but you do not expect to pay for every succeeding crop that is taken off your land after you have bought it.

It is very difficult to understand why the Government should discrimin. ate in taxation between privately-owned land used to grow a crop of trees and land used for a farm crop. When the land of a tree farm has been 
bought and paid for, the Government's equity should be confined to the land tax and school tax, as in the case of any other farm.

In past years there has been a good deal of propaganda designed to create the impression that without more Government ownership and control of forest lands, we are headed for a catastrophe. This is, I think, largely a reflection of similar propaganda in the United States. There it is understandable, with 80 per cent of the forest land still in private ownership. In British Columbia with 90 per cent in State ownership it would seem, more reasonable to try to increase the interest of the private citizen in raising this crop so natural to the Province, and so important for its prosperity.

At any rate no hindrance should be put in the way of anyone who wants to buy suitable forest land and who undertakes to keep it productive. Until the Government has its own tremendous forest estate in satisfactory condition it should welcome those who wish to relieve it of some of its burden, especially as private land will contribute to the Treasury through taxation while the trees are growing. (with Government ownership no revenue would be obtained).

I have just one more point-the relation of State to private foresters. The Forest Act Amendment Act, now before the House, provides that only those who employ a graduate forester from a school approved by the Minister shall be granted a forest management licence, unless the area is too small for a full-time forester, when the Department will provide professional advice at cost.

Some of us may be inclined at first to think this is a step in the right direction, and helpful to the profession; or else, assuming that the Minister will naturally approve our own particular University, may think it does not affect us.

This Society should consider this matter very carefully. By proposing this legislation the Minister admits that, in his opinion, it is necessary that a person practising as a forester should be properly qualified. He proposes to define the standard of qualification himself.

For two years the profession has been preparing a Bill to authorize a qualified Board of Examiners of the profession to register foresters. It hopes to have this Bill introduced at this Session. Objections are not warranted that such registration might deprive men of their living who, not being University trained have, none-the-less, successfully practised forestry for years. That is provided for in the Foresters' Bill. The Government Service itself has had throughout its lifetime, and still has, senior foresters, able and efficient, who are not University graduates. It would be anomalous to require by Statute qualifications for foresters in private employment which are not required in the Government service.

Moreover, I think we should consider whether it is in the interest of the profession, or in the public interest, that a Minister should be burdened with the responsibility for deciding which school is satisfactory, and which is not. Is it in the public interest, or within the bounds of democratic principle and custom, that a Minister of the Crown should have this power to say who shall and who shall not be employed by a private company? 
We are all agreed that the Government should lay down standards of forest management. There is no need to go further. If these standards are not lived up to it has the remedy.

This principle need only be applied to other professions to condemn it. The Medical Association, the Bar Association, the Association of Professional Engineers would be replaced by a Minister of Health, an Attorney-General, a Minister of Public Works, and a Minister of Mines. You can give your name to this kind of administration. I suggest that this Society request the Government to withdraw this provision of the Bill. It is my understanding that the Minister of Forests is willing to do this if our Foresters' Bill is enacted. I wish also to draw your attention to the next clause providing that lessees of small units may hire the services of a Government forester. I am sure the foresters who are trying to make a living as consultants will agree with me that this is quite out of bounds. If such lessees require the advice of a professional forester in order to make and operate a management plan acceptable to the Government, they could engage the services of a consulting forester. The Forest Service already has too much work for its small staff. The principle behind these two clauses is alarming. They should, by no means, be permitted to become the law of the land without the most vigorous protest. They are Section 12, sub-sections 16 and 17 .

Finally, I would say that the State's relation to private forestry in British Columbia has been throughout its history, including the current Forest Act amendments, that of a shrewd and hard trader. It has always tried to get 100 cents for a dollar, and sometimes a bit more, as many bankrupt loggers and timber licencees during the years would testify. I feel assured that the public Treasury will not suffer, but will greatly gain, by the fulfilment of the programme laid down in Mr. Kenney's new bill. In my opinion any Company that he can persuade to sign on the dotted line will have to work hard and efficiently to make anything on its investment.

Its forester, instead of becoming wealthy, may have to be satisfied, if his directors and shareholders will support him, with the reward of seeing his trees grow and his forest develop into the pride of the district, a show place for visiting foreigners, a stable source of employment, the pillar of its community prosperity. May he succeed. But even if Mr. Kenney makes it too hard for him and if his trees fail him, I feel sure he will earn from some future Minister of Forests the sympathy and commendation of the old gard. ener by Orlando:

"O good old man, how well in thee appears

The constant service of the antique world, When service sweat for duty, not for need!

Thou art not for the fashion of these times,

Where none will sweat but for promotion,

And having that do choke their service up

Even with the having: it is not so with thee.

But, poor old man, thou prunest a rotten tree,

That cannot so much as a blossom yield

In lieu of all thy pains and husbandry." 